Rev. Biol. Trop. 52(1): 77-83, 2004

www.ucr.ac.cr www.ots.ac.cr www.ots.duke.edu

\title{
The genera of Chrysomelinae (Coleoptera: Chrysomelidae) in Costa Rica
}

\author{
R. Wills Flowers \\ Center for Biological Control, Florida A\&M University, Tallahassee, FL 32307 USA; rflowers@ mail.istal.com \\ Received 04-III-2003. Corrected 10-I-2004. Accepted 12-II-2004.
}

\begin{abstract}
Keys in Spanish and English are given for the genera of Chrysomelinae known from Costa Rica. For each genus, a list of species compiled from collections in the University of Costa Rica, the National Biodiversity Institute, and the entomological literature is presented. The genus Planagetes Chevrolat 1843 is recorded for the first time from Central America, and the genus Leptinotarsa Stål 1858 is synonymized with Stilodes Chevrolat 1843.
\end{abstract}

Key words: Chrysomelinae, keys, Planagetes, Stilodes, Leptinotarsa.

Members of the subfamily Chrysomelinae -popularly known in Costa Rica as "confites con patas" (walking candies)- are among the largest and most colorful representatives of the family Chrysomelidae in Costa Rica. They are of broad ecological interest because of their host plant preferences and varying modes of life. Although readily noticed, there are no keys to the Neotropical fauna for identification of either species or genera, and many taxonomic problems persist in this subfamily. The only recent generic key for this region was published in 1965 by Jan and Bohumila
Bechyné for Venezuela. To assist present and future workers studying this group, a modified version of their key for genera known to occur in Costa Rica is presented in English and Spanish. This is followed by notes on the diversity of the individual genera in Costa Rica with a list of both species identified in the collections of the University of Costa Rica and the National Biodiversity Institute (INBio) and those recorded from Costa Rica in the catalogs of Blackwelder (1947) and Bechyné (1952), along with a discussion of the taxonomic status of Stilodes and Leptinotarsa.

\section{Clave para los géneros de Chrysomelinae conocidos de Costa Rica}

(adaptada de Bechyné \& Bechyné 1965)

1. Uñas tarsales simples (Fig. 2), tibias no anguladas dorsalmente; primer esternito abdominal sin costillas se-

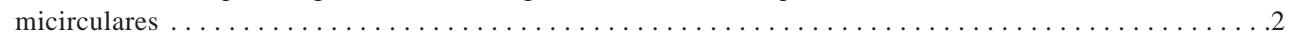
Uñas tarsales apendiculadas (Fig. 1), lados externales de las tibias con angulo obtuso en el cuarto apical; primer esternito abdominal con costillas semicirculares (Fig. 10) $\ldots \ldots \ldots \ldots \ldots \ldots$. . . . . . . . .

2. (1) Margen apical del los epipleuros con una hilera de setas cortas (Fig. 4) . . . . . . . . . . DORYPHORINI 3 Margen apical del los epipleuros glabros $\ldots \ldots \ldots \ldots \ldots \ldots \ldots \ldots \ldots \ldots \ldots \ldots \ldots \ldots \ldots$ CHRYOMELINI 9

3. (2) Prosterno sin proceso intercoxal, mesosterno sin una espina distinta (Fig. 8) $\ldots \ldots \ldots \ldots \ldots \ldots \ldots \ldots$ Proceso intercoxal del prosterno alto, o mesosterno con una espina distinta dirigida hacia adelante (Fig. 7, 9) . .7 
4.(3) Tercer segmento del palpo maxilar a menudo más larga y ancha que el segundo (Fig. 5); élitro blanco, blanco-amarillo, o blanco-rosado con rayas oscuras o un patron complejo de manchas oscuras (Fig. 11) . . . . . . . . . .5 Tercer segmento del palpo maxilar a menudo más corta y delgada que el segundo (Fig. 6); élitro nunca blancuzco

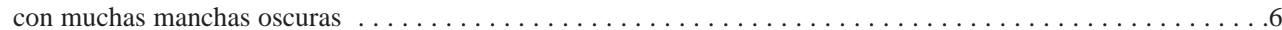

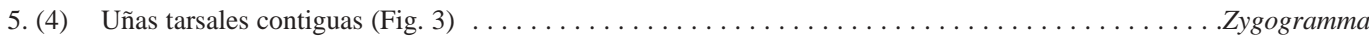

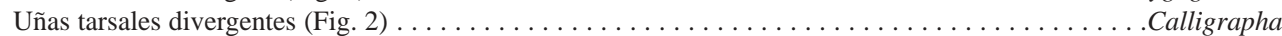

6. (4) Mesosterno sobresale un poco bajo del prosterno; fémur delantero del macho con una muesca honda Labidomera Mesosterno continuo con el prosterno; fémur delantero simple en ambos sexos Stilodes (incluyendo Leptinotarsa)

7. (3) Proceso intercoxal del prosterno alto y prominente; mesosterno continuo con el prosterno

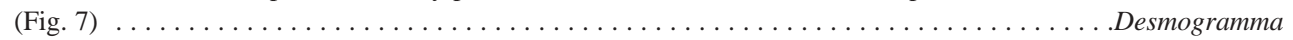
Prosterno normal, mesosterno con una espina mediana a grande dirigido hacia adelante (Fig. 9) . . . . . . . .8

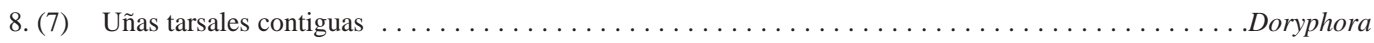

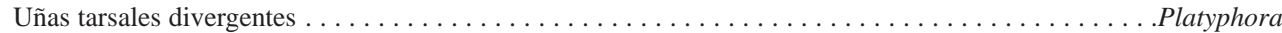

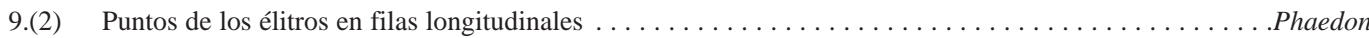

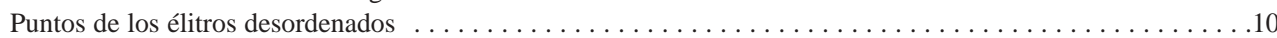

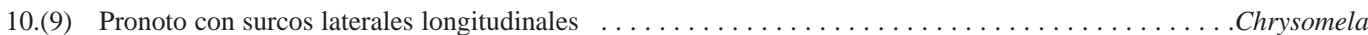
Pronoto sin surcos laterales longitudinales $\ldots \ldots \ldots \ldots \ldots \ldots \ldots \ldots \ldots \ldots$. $\ldots \ldots \ldots$. $\ldots \ldots$. $\ldots \ldots$. $\ldots \ldots$

\title{
Key to the genera of Chrysomelinae known to occur in Costa Rica
}

\author{
(adapted from Bechyné \& Bechyné 1965)
}

1. Tarsal claws simple (Fig. 2), tibiae not angulate dorsally; abdominal sternite 1 without costae $\ldots \ldots \ldots .2$ Tarsal claws appendiculate (Fig. 1), tibiae obtusely angulate in apical fourth; abdominal sternite 1 with two semi-

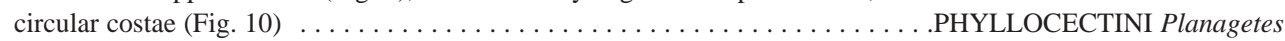

2. (1) Elytral epipleuron with apical margin bearing a row of short setae (Fig. 4) . . . . . . . . . . DORYPHORINI 3 Elytral epipleuron with apical margin bare $\ldots \ldots \ldots \ldots \ldots \ldots \ldots \ldots \ldots \ldots \ldots \ldots \ldots \ldots$ CHRYSOMELINI 9

3. (2) Prosternum not raised anterior to fore coxae, mesosternum lacking a distinct horn (Fig. 8) . . . . . . . . . . .4 Prosternum sharply angled upward anterior to fore coxae, or mesosternum with a distinct horn directed anteriorly

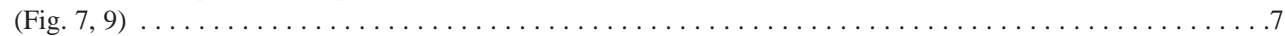

4.(3) Third segment of maxillary palp usually longer and wider than second; elytra white, yellowish white or pinkish white with dark stripes or a complex pattern of dark spots $($ Fig. 11) $\ldots \ldots \ldots \ldots \ldots \ldots \ldots \ldots \ldots \ldots$ Third segment of maxillary palp generally shorter and narrower, or subequal to second; elytra variously colored but

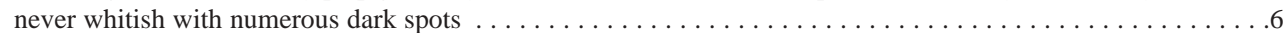

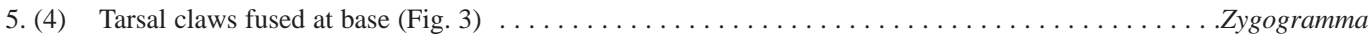

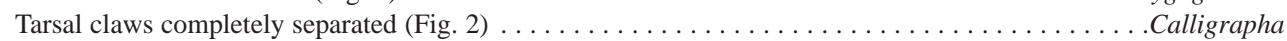

6. (4) Mesosternum projects slightly below the prosternum; fore femur of male with a deep notch . . . . . . Labidomera Mesosternum continuous with prosternum; fore femur of both sexes simple .. .Stilodes (including Leptinotarsa)

7. (3) Prosternum sharply angled upward anterior to forecoxae; mesosternum continuous with prosternum

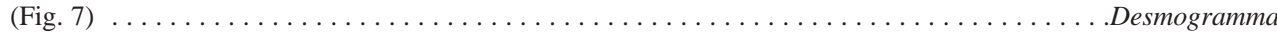
Prosternum flat, mesosternum produced as a medium to large curved horn (Fig. 9) $\ldots \ldots \ldots \ldots$

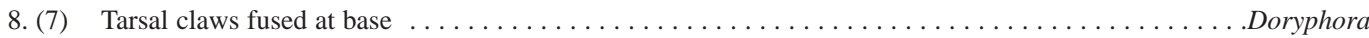

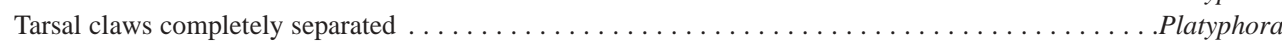




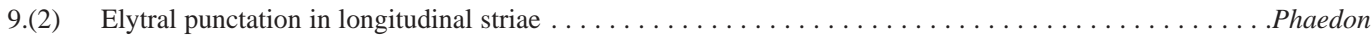

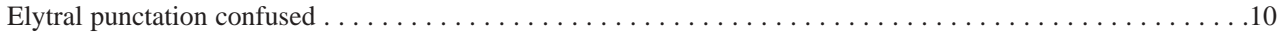

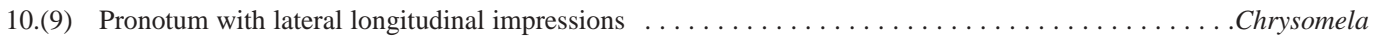
Pronotum lacking lateral longitudinal impressions $\ldots \ldots \ldots \ldots \ldots \ldots \ldots \ldots \ldots \ldots \ldots \ldots \ldots \ldots \ldots \ldots \ldots \ldots \ldots \ldots$

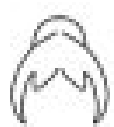

1

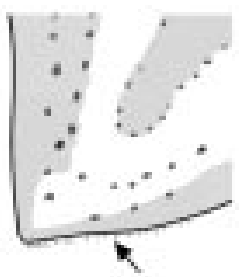

4

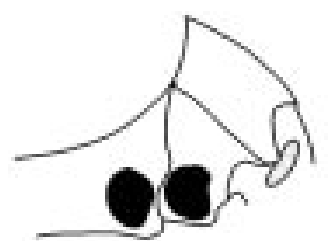

7

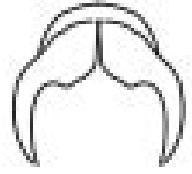

2

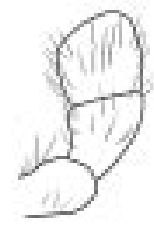

5

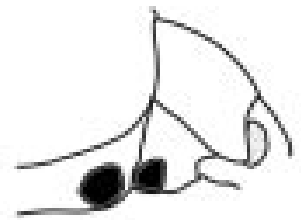

8

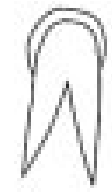

3

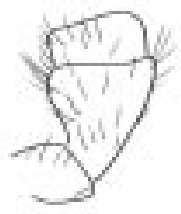

6

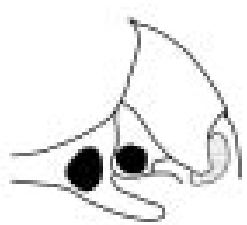

9

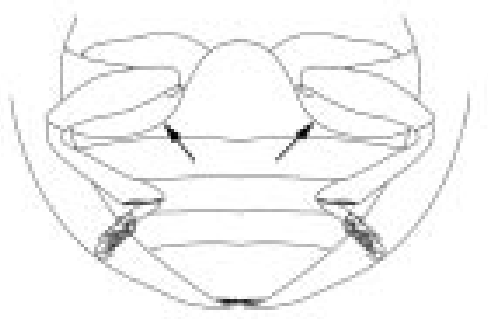

10

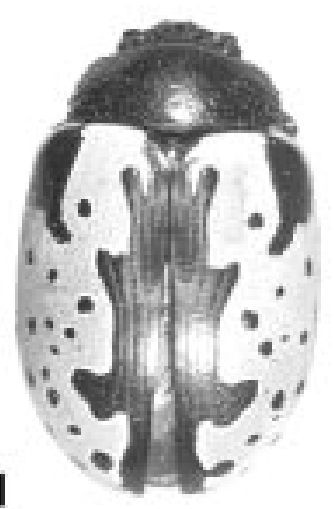

Figs. 1-3, tarsal claws: 1, Planagetes; 2, Calligrapha; 3, Zygogramma. Fig. 4, apex of elytron of Zygogramma: row of setae indicated by arrow. Fig. 5-6, maxillary palpi: 5, Zygogramma; 6, Platyphora. Fig. 7-9, side view of thorax: 7, Desmogramma; 8, Stilodes; 9, Platyphora. Fig. 10, underside of abdomen of Planagetes: semicircular ridges indicated by arrows. Fig. 11, dorsal view of Calligrapha ramulifera. 


\section{Notes on the genera}

Calligrapha Chevrolat 1837

Adult specimens of all species have white, pale yellow, or pale rose elytra with intricate patterns of dark markings. Twelve species are presently known from Costa Rica:

Calligrapha argus Stål

Calligrapha diversa (Stål)

Calligrapha elegantula Jacoby

Calligrapha fulvipes Stål

Calligrapha gyllenhali Stål

Calligrapha notatipennis Stål

Calligrapha pantherina Stål

Calligrapha ramulifera Stål

Calligrapha serpentina (Rogers)

Calligrapha sponsa Stål

Calligrapha subdentata Bechyné

Calligrapha tortilis Stål

\section{Chrysomela Linné 1758}

Several specimens of Chrysomela scripta (Fabr.), a Nearctic species, have recently been collected from higher elevations. In one case, the species was damaging planted alder trees.

Desmogramma Erichson 1847

One species, Desmogramma conjugata Stål, is known from Costa Rica.

\section{Doryphora Illiger 1807}

Two species occur in Costa Rica and are the largest members of the Costa Rican chrysomelid fauna.

Doryphora bioleyi (Achard)

Doryphora paykulli (Stål)

\section{Labidomera Chevrolat 1837}

One species, Labidomera suturella Guérin-Méneville occurs in Costa Rica. Choe (1989) reported maternal care in this species.
Phaedon Latreille 1829

Three species are recorded from Costa Rica:

Phaedon cyanescens Stål

Phaedon mexicanum Jacoby

Phaedon ruficeps Achard

\section{Plagiodera Chevrolat 1837}

Three species are known from Costa Rica. Plagiodera atritarsis Stål

Plagiodera bistripunctata Duvivier

Plagiodera quadrimaculata Jacoby

Planagetes Chevrolat 1843

One species, Planagetes uniformis (Jacoby) new combination occurs in Costa Rica. Jacoby described this species in Plagiodera, noting its small round body outline and its similarity to a coccinellid. However, this species has appendiculate claws and angulate tibia, both characters of Planagetes (Bechyné \& Bechyné 1965). This is a new Central American generic record. Along with its coccinellid-like habitus, P. uniformis has semi-circular costae on the first abdominal sternum behind the metacoxae (Fig. 10), a character also found in many Coccinellidae.

\section{Platyphora Gistl 1857}

This is the largest genus of Chrysomelinae in Costa Rica. Twenty-three species are known and many as-yet unidentified specimens have also been collected. Vivipary has been observed in at least two Costa Rican species and is known from a number of South America species. However, the biology of most of the species is still unknown.

Platyphora arangoi (Jacoby)

Platyphora bicolor (Jacoby)

Platyphora biremis (Stål)

Platyphora decorata (Jacoby)

Platyphora decurrens (Stål) 
Platyphora eucosoma (Stål)

Platyphora flavoguttata (Jacoby)

Platyphora ligata (Stål)

Platyphora macrogramma Bechyné

Platyphora nigroguttata (Stål)

Platyphora nr. lativittis (Jacoby)

Platyphora ocellata (Jacoby)

Platyphora ornata (Jacoby)

Platyphora panamensis (Jacoby)

Platyphora petulans (Stål)

Platyphora punctipennis (Jacoby)

Platyphora purulensis (Jacoby)

Platyphora rogersi (Jacoby)

Platyphora salvini (Baly)

Platyphora selva Daccordi

Platyphora semiviridis (Jacoby)

Platyphora spectabilis (Stål)

Platyphora spectanda (Stål)

Platyphora uniformis (Jacoby)

\section{Stilodes Chevrolat 1843 \\ Leptinotarsa Stål 1858 new synonymy}

Although it contains one of the most studied animals on Planet Earth, the genus Leptinotarsa has never been adequately differentiated from other genera in the Doryphorini. Given the enormous economic impact of the Colorado Potato Beetle, Leptinotarsa decimlineata (Say), and the increasing interest in finding some alternative to pesticide control, it is strange that the status of the genus Leptinotarsa has not attracted more interest. Jacoby (1880-1892), in the Biologia Centrali Americana noted the high degree of similarity between Leptinotarsa and Stilodes and the difficulty in correctly assigning some of the Central American species. Stål (quoted by Jacoby) recognized Leptinotarsa on the basis of the last segment of the maxillary palp which he described as shorter than the penultimate, and truncate. Chapuis (1875) used the longer length of the tibial groove to separate Leptinotarsa. Bechyné and Bechyné (1965) used the form of the antennae; short and subclavate in Stilodes, filiform in Leptinotarsa. The only recent attempt at a taxonomic treatment was Jacques' (1988) short booklet on
Leptinotarsa, but this work ignored the species south of Mexico, and comparisons with other genera were limited to meaningless tabulations of species numbers among North American Doryphorini. Likewise, Hsiao (1988) compared Leptinotarsa only to other Nearctic Doryphorini. Neither author mentioned Stilodes.

After studying four species assigned to Leptinotarsa and seven species assigned to Stilodes in the INBio collection, I conclude that none of these characters is reliable. Most species in both these genera have the last two segments of the maxillary papli subequal, and in neither genus is the last segment consistently longer or shorter than in the other (they are truncate in all the species). Indeed, the last segment appears to be somewhat retractable into the third segment because in some specimens the length ratios are noticeably different from side to side.

The tibial groove is also an unreliable character. In species assigned to Leptinotarsa it purportedly runs down the entire apical half of the tibia while it is confined to the apical third in those of Stilodes. However, in all species the beginning of the groove is extremely shallow somewhere between the apical half or third of the tibia. The angle of the light can often change the point at which the groove appears to begin. Jacoby also noted the variability of this character.

Finally, there is no difference in shape of the antennae between the two genera in Costa Rica. All have the apical antennomeres somewhat thicker than the basal antennomeres.

Examination of the male and female genitalia also failed to provide any consistent characters for separation. The spermathecae of most of the species in both genera had the same general form, and showed as much intraas intergeneric variation. The aedeagi were similar except for some differences in the apex of the median lobe. In Costa Rican Stilodes the lateral margins are sinuate (viewed from the side), while in Leptinotarsa they are evenly curved. At least one other species of Leptinotarsa, however, also has a sinuate apicolateral margin of the 
median lobe (Jaques 1988). Nor would the tip of the median lobe in and of itself be considered a valid way to separate genera in many other groups of Coleoptera.

Stilodes is a large and probably polyphyletic genus, largely South American in distribution. Both it and Leptinotarsa are in need of modern taxonomic revisions. For the present, there are no characters or combination of characters that reliably separate these taxa and hence no justification for keeping them as separate genera. Unfortunately for the applied entomological literature and those overly concerned with "taxonomic stability", Stilodes Chevrolat 1843 has nomenclatural priority.

Stilodes belti (Jacoby)

Leptinotarsa belti Jacoby new synonymy

Stilodes decimlineata (Say)

Leptinotarsa decimlineata Say

new synonymy

Stilodes evanescens (Stål)

Leptinotarsa evanscens Stål

new synonymy

Stilodes flavitarsis (Guerin-Meneville)

Leptinotarsa flavitarsis Guerin-Meneville new synonymy

Stilodes fuscolineata (Stål)

Stilodes haldemani (Rogers)

Leptinotarsa haldemani Rogers

new synonymy

Stilodes leoparda Jacoby

Stilodes modesta Jacoby

Stilodes motschulkyi Stål

Stilodes neptis (Stål)

Stilodes panamensis Jacoby

Stilodes quadristriata Jacoby
Stilodes undecimlineata (Stål)

Leptinotarsa undecimlineata Stål

new synonymy

Zygogramma Chevrolat 1837

Species in this genus have Calligraphalike markings of white to yellowish white, overlain with dark stripes or irregular blotches.

Seven species have been recorded from Costa Rica and several more unidentified ones are in the INBio material.

Zygogramma bigenera (Stål)

Zygogramma curvatolineata Jacoby

Zygogramma guttulosa (Stål)

Zygogramma picecollis Stål

Zygogramma popa (Stål)

Zygogramma signatipennis (Stål)

Zygogramma violaceomaculata (Jacoby)

\section{ACKNOWLEDGMENTS}

This study was funded by the Costa Rica National Biodiversity Inventory and the Biodiversity Resources Development Project, GEF/World Bank. This study was also funded in part by a grant (FLAX 91005) from CSREES, USDA to Florida A\&M University.

\section{RESUMEN}

Se presenta claves en español y inglés para los géneros de Chrysomelinae conocidas de Costa Rica. Para cada género, se presenta una lista de especies compiladas de las colecciones de la Universidad de Costa Rica, el Instituto Nacional de Biodiversidad, y la literatura entomológica. El género Planagetes Chevrolat 1843 está registrado por primera vez de América Central, y el género Leptinotarsa Stål 1858 está sinonomizado con Stilodes Chevrolat 1843.

\section{REFERENCES}

Bechyné, J. 1952. Nachträge zu de Katalogen von Blackwelder und Junk-Schenkling der neotropischen echten Chrysomeliden (Col. Phytophaga). Entomologische Arbeiten aus dem Museum G. Frey 3: $1-62$. 
Bechyné, J. \& B. Springlová de Bechyné. 1965. Notes sur les Chrysomelidae s. str. de Venezuela et des pays limitrophes. Revista de la Facultad de Agronomía (Maracay) 3: 44-110.

Blackwelder, R.E. 1947. Checklist of the coleopterous insects of Mexico, Central America, the West Indies, and South America. Smithsonian Institution, United States National Museum Bulletin 185, Part 4: 551763.

Chapuis, F. 1875. In Histoire Naturelle des Insectes. Genera des Coléoptères. T. Lacordaire \& F. Chapuis (eds.) 11: 1-420.
Choe, J.C. 1989. Maternal care in Labidomera suturella Chevrolat (Coleoptera: Chrysomelidae) from Costa Rica. Psyche 96: 65-67.

Hsiao, T.H. 1988. Host specificity, seasonality and bionomics of Leptinotarsa beetles. In P. Jolivet, E. Petitpierre and T.H. Hsiao (eds.). Biology of Chrysomelidae. Kluwer Academic Publishers. Dordrecht. $615+x$ vii pp.

Jacoby, M. 1880-1892. Biologia Centrali-Americana, Insecta, Coleoptera, vol. 6, pt. 1; Suppl. 1-168; 1-348

Jaques, R.L. 1988. The potato beetles. Flora \& Fauna Handbook No. 3. E.J. Brill, Leiden, 144 p. 
